Archives de sciences sociales des religions

109 | janvier-mars 2000

Formes religieuses caractéristiques de

l'ultramodernité : France, Pays-Bas, États-Unis, Japon, analyses globales

\title{
The Abstract Image of God: The Case of the Dutch Youth
}

Jacques Janssen and Maerten Prins

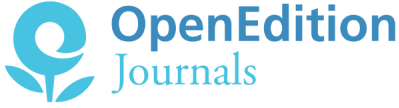

Electronic version

URL: http://journals.openedition.org/assr/20171

DOI: 10.4000/assr.20171

ISSN: $1777-5825$

Publisher

Éditions de l'EHESS

Printed version

Date of publication: 1 March 2000

Number of pages: $31-48$

ISBN: 2-222-96690-6

ISSN: 0335-5985

Electronic reference

Jacques Janssen and Maerten Prins, "The Abstract Image of God: The Case of the Dutch Youth », Archives de sciences sociales des religions [Online], 109 | janvier-mars 2000, Online since 19 August 2009, connection on 19 April 2019. URL : http://journals.openedition.org/assr/20171; DOI : 10.4000/ assr.20171

This text was automatically generated on 19 April 2019.

(c) Archives de sciences sociales des religions 


\title{
The Abstract Image of God: The Case of the Dutch Youth
}

\author{
Jacques Janssen and Maerten Prins
}

1 In the ongoing European secularisation process, the Netherlands took the lead by the end of the seventies. Church membership is lowest in all of Western Europe. Studies by Dutch sociologists show a steady decline of religious organisations, opinions and behaviour (see for an extensive review Becker \& Vink, 1994). The figures seem clear and unambiguous. In $1945,40 \%$ of the Dutch population were Catholics; in the year 1992 this was $22 \%$ and in the year 2020 this percentage is predicted to be 15 . For the Protestant denominations the figures are even more telling. In 1945, their percentage was above 40; in the year 1992 this was 18 , and in the year 2020 it will be below 10 . The percentage of non-Church-members was 15 in 1945, in 1992 it was 57 and it is predicted to rise to 73 in 2020 (ibid.: 175-180).

When we add to these facts and predictions the trend that in all European countries the younger generation scores substantially lower on almost all aspects ofreligious behaviour than older people (Campiche, 1997), we can deduce that the Dutch youth is at the summit of secularisation. Indeed we found in a national survey among the Dutch youth (1991, mean age 23.9) that $61 \%$ are not members of a Church (De Hart \& Janssen, 1993). In the European Values Study of 1990 a somewhat lower percentage of 53 was reported (age group of 18 up to 29; Campiche, 1997: 52), which is nevertheless the highest in Western Europe. Several other studies show similar or even substantially more negative results (Van der Linden, 1989; De Hart, 1990; Alma, 1993; Van der Ven \& Biemans, 1994; Becker, De Hart \& Mens, 1997). In parishes and Church organisations all programmes designed to attract the young appear to fail (Bernts, 1995; Van der Ven, 1995). The Churches are losing contact with the younger generation and in the years to come the results of this mutual estrangement will become more and more visible in participation and opinion indexes.

3 In Europe as a whole the consequences of secularisation are stronger in dominantly Protestant countries where participation in Church and Church-related organisations declines more strongly and more rapidly (Campiche, 1997: 47). In the Netherlands this is reflected in the steep decline over the past decades of the largest Protestant group 
("Hervormden") but since the sixties the Catholics have had to face the most turbulent development (Dekker et al., 1997). Their numbers declined considerably and while in the whole of Europe the Protestants score lower on religious indexes, in the Netherlands it is the Catholics who show lower scores: they go to church less, are less interested in religion, pray less, pay less and so on (Dekker et al., 1997). It is even contended that $41 \%$ of the Dutch Catholics have to be labelled as "non or weak believers"(Peters et al., 1996: 20). For the Catholic youth this applies a fortiori. Even the most active among them, those who participate in church choirs, have their doubts on all kinds of religious issues and show the same religious profile as the rank and file members (Bernts, 1995: 99).

In the European Studies (Campiche, 1997: 54) the exceptional position of the Dutch Catholics is related to the debate between the Dutch Catholic Church and the Vatican in the sixties. However, this could very well be only the symptom of a much more complicated issue, in which the docility of the Dutch Catholics that once made them an example of obedience plays a major role. In the first half of the XXth century, deviant opinions and criticism were not tolerated within the strictly hierarchical Dutch Catholic Church. The successful emancipation of the Dutch Catholics on the social, cultural and political level can be accredited to this strategy of unity. However, the drawback became apparent in the second half of the 20th century. When the authority of the Church was challenged it faded overnight and the internal motivation of its adherents turned out to be weak. Leaving its shepherds the flock went astray (Roes, 1994).

5 The secularisation process is often presented as an ongoing, one-way decline of religion. This line of argument can be criticised by showing the complexity and multidimensionality of the secularisation process in the Netherlands (Janssen, 1998). While the above-mentioned facts will not be questioned as such, there is indeed much more to say on religion than simply regarding it as a fading phenomenon. Generally only very few young people reject religion explicitly or prefer atheism. They do still show a religious identity, but it has become a private affair, insecure, non-specific and abstract. This is found inside as well as outside the Churches. In the European studies, the Dutch youth, the group with the lowest number of Church members, score rather high (5th place among 16 countries) when religion is not measured by membership but as an individual characteristic indicated by church attendance, prayer and the salience of religion in one's life (Campiche, 1997: 59).

6 To elaborate on this point, we will first show that the religion of the Dutch youth does not exist. There are several religions and religious practices. Moreover, we should not forget that non-religious people also differ fundamentally on several existential issues and practices. To depict the full range of the Dutch youth, religious as well as non-religious, we will have to distinguish nine different groups. Secondly, lots of studies have shown low participation of young people in Church affairs. They also show that the young have hardly any knowledge about institutional religion. In the Netherlands many people, regardless of their educational level, do not know what Easter is about, let alone Pentecost or Ascension Day. Of course there is a problem in what the young do not do and do not know, but we are more interested in what they actually do and what they actually know. We also want to hear it in their own language and therefore our research is predominantly based on the analysis of open ended questions. The multiple choice examination method that several surveys apply can be useful in some cases, but has its shortcomings when it comes to fully understanding how young people construct their religion. In general, open ended questions are to be preferred over closed questions when 
the behaviour and concepts of people are subject to constant change and reconstruction. If that is the case, old concepts soon lose theirvalidity and new concepts have to be explored. Besides, we are living in an age of cultural change, marked by individualisation and differentiation: people have to construct their own concepts. In a way they have to be inventors. Religious beliefs and practices are increasingly shaped outside the traditional institutional Churches and become more and more individualised and diverse (Dekker et al., 1997). To understand the religious practices of today's youth, we have to study their thinking process and not just the conclusions of this process (Spilka et ai, 1985: 69). Using open ended questions is therefore the best, if not the only way to get an insight in contemporary religious practices amongst youngsters. So we asked young people to tell us about their religious feelings in their own words. By using open ended questions, we also avoid the problem of scaring off youngsters with words and images on the subject of religion. For instance, the word "God" seems to have an intimidating effect on youngsters: when asked straight out whether they pray to God, only $11 \%$ assent, but when asked how they pray, in an open ended question, $30 \%$ of the youngsters spontaneously mention God as the direction of their prayer (see further on). So, asking a question does not always give us the answer, whereas not asking the question does. The famous advice that Polonius gives to his servant Reynaldo: "by indirections find directions out" (Shakespeare, Hamlet, act II, scene I) certainly applies here.

7 The research was carried out in 1991 (De Hart \& Janssen, 1993) and the sample consisted of 687 Dutch youngsters with an average age of 23.9 years (male $44 \%$, female $56 \%$ ). of these youngsters $62 \%$ attend school, among them $57 \%$ go to university. The conclusions therefore relate to the better educated, elder youth, in due time an important segment of opinion leaders in society.

8 To analyse the answers to the open ended questions, we use a computerised technique called Textable (Janssen, 1990). This computer programme allows us to handle texts, to categorise them and to link them with data from closed questions. One of the advantages of Textable is the possibility of interaction between open and closed information processing. It is also possible to continuously control and adapt the category system and return to the original answers at any point in the analysis.

\section{The diversity of the religiosity of the Dutch youth}

9 The Netherlands is a plural country in name and in character. It has since long been a country of several religious minorities that lived in harmony, in what was called a pillarised society. In the sixties this plural society pluralised even more as a result of the processes of secularisation, individualisation and the emergence of new religious movements, here summarised as New Age (Janssen, 1998). In order to construct a category system for religious involvement, we make use of traditional sociological variables like "church membership" and "church attendance" (more or less than three times a year). But in order to categorise the non-religious youngsters, we also have to use personal variables. We opt for the variable "praying" (regularly or sometimes, versus never), because this seems to be the most persistent religious element in a secularised society (Campiche, 1997; Janssen et al., under review), and the variable "engagement in New Age activities", since New Age is the most successful recent movement that includes various activities and captures the process of individualisation and change in religious 
concepts. By combining these sociological and personal variables, we can distinguish nine religious groups (Table 1).

Table 1 - The construction of a category system for religious involvement. $\mathrm{N}=687$.

\begin{tabular}{|c|c|c|c|c|c|c|}
\hline $\begin{array}{l}\text { VARIETIES OF } \\
\text { REIIGIOUS } \\
\text { INVOLVEMENT }\end{array}$ & $\begin{array}{l}\text { CHURCH } \\
\text { MEMBERSHIP }\end{array}$ & PRAYING & $\begin{array}{l}\text { CHURCH } \\
\text { ATTENDANCE }\end{array}$ & $\begin{array}{l}\text { NEW AGE } \\
\text { ACTIVITIES }\end{array}$ & $\%$ & $\mathrm{~N}$ \\
\hline 1 ORтноDоX & member & praying & $\begin{array}{l}\text { church } \\
\text { attendance }\end{array}$ & & 4 & 26 \\
\hline 2 CALvinist & member & praying & $\begin{array}{l}\text { church } \\
\text { attendance }\end{array}$ & & 7 & 46 \\
\hline 3 REFORMED & member & praying & $\begin{array}{l}\text { church } \\
\text { attendance }\end{array}$ & & 7 & 46 \\
\hline 4 САтноL & member & praying & $\begin{array}{l}\text { church } \\
\text { attendance }\end{array}$ & & 11 & 79 \\
\hline 5 MARGINAL. & member & & & & 9 & 60 \\
\hline 6 NEW AGE & & praying & & $\begin{array}{l}\text { at least six } \\
\text { activities }\end{array}$ & 15 & 106 \\
\hline 7 EX-MEMBER & ex-member & praying & & $\begin{array}{l}\text { less than six } \\
\text { activities }\end{array}$ & 17 & 119 \\
\hline 8 DOLBTER & & praying & & $\begin{array}{l}\text { less than six } \\
\text { activities }\end{array}$ & 9 & 60 \\
\hline 9 NON BEL.IEVER & & & & & 17 & 119 \\
\hline NO CATEGORY & & & & & 4 & 26 \\
\hline
\end{tabular}

The first distinction is the traditional one between Church members and non-Church members. This sociological variable still works, albeit for a decreasing segment of the youth. In our research $39 \%$ of the youngsters are still members of a Church. Within this group we discern Orthodox Protestants (4\%), Calvinists (7\%), Reformed Protestants (7\%) and Catholics (11\%). It is known from previous research that these groups show a decreasing measure of participation and conviction (Peters \& Schreuder, 1987; De Hart, 1990; Felling et al., 1991; Dekker et al., 1997). Furthermore there are those who consider themselves members of a Church, but either never attend church, or never pray. We labelled them Marginals (9\%).

For the remaining $61 \%$ that are not affiliated to a Church, we devised a new heuristic scheme. Usually this group is not differentiated any further. In our opinion this is a mistake: apostasy is as multicoloured as conversion and disbelief is as complex as belief (Pruyser, 1974). Besides, the non-denominational people are also individualised and construct their own particular way of life. Of particular interest is the increasingly popular New Age movement. The core beliefs of New Age can be summarised by the following assumptions: apart from the sensorial reality, there is an invisible and spiritual reality that, in principle, can be accessed by everyone; there is a holistic coherence in nature; by way of transformation and reincarnation everything and everyone is in continuous growth towards a higher spiritual level; and a new era and a new world order - the "age of Aquarius"- is imminent (Stenger, 1989; Hanegraaff, 1996; Becker et al., 1997). Whereas traditional Churches are characterised by a clear structure, organisation and membership, New Age is not a ready-made system of beliefs, but it is undefined, vague and constantly changing. New Age is characterisedby a broad variety of traditions, practices, techniques, therapies and beliefs. To distinguish New Age youngsters, we presented a list of 12 fields of interest: yoga, reincarnation, astrology, extraterrestrial civilizations, parapsychology, macrobiotics, anthroposophy, homeopathy, the New Age 
movement, Buddhism, Zen and holism (De Hart \& Janssen, 1992). Youngsters not affiliated to a Church who participate in activities related to six or more of these issues are considered New Age-minded (16\%).

The seventh group is made up of the former members of Churches, the Ex-members (18\% ). Their only religious activity is praying. The eighth group, labelled Doubters (9\%), were never affiliated to any Church, but do pray at least sometimes. The last group are the Non-believers (18\%). They lack any kind of religious involvement whatsoever. They are in the words of Max Weber - "religiös unmusikalisch", tone-deaf to religion.

We predicted beforehand that this heuristic category system for religious involvement would reflect a rank order of orthodoxy. In every table Pearson-r and eta are represented. When the Pearson-correlation is high and the eta does not substantially differ, the rank order model we predicted holds. Looking at variables directly related to religion, this prediction is indeed strongly validated. When asked about the importance of being a good Christian (V57), agreement that conciliation with death is only possible by having faith in God (V534), and the importance of being close to God (V84), correlations are very high (.70 to.72) and linear (the eta hardly diverges). The definition of a higher reality (V418) also correlates strongly (.68) and linear. The most religiously involved youngsters - the orthodox Protestants - believe that there is a God. The less religiously involved the youngsters are, the more they tend to answer that there is a higher being, or that they don't know, and most of the non-believers say that God does not exist (Table 2).

Table 2 - Scores of the nine religious groups on variables directly related to Christian religion.

\begin{tabular}{|c|c|c|c|c|c|c|c|}
\hline \multirow[b]{2}{*}{$\begin{array}{l}\text { RELIGIOUS } \\
\text { INVOLVEMENT }\end{array}$} & \multirow{2}{*}{$\begin{array}{l}\text { V84 close } \\
\text { to God } \\
\text { mean } \\
\text { seore }\end{array}$} & \multirow{2}{*}{$\begin{array}{l}\text { V534 } \\
\text { trust God } \\
\text { death } \\
\text { mean } \\
\text { score }\end{array}$} & \multirow{2}{*}{$\begin{array}{l}\text { V57 good } \\
\text { Christian } \\
\text { mean score }\end{array}$} & \multicolumn{4}{|c|}{$\begin{array}{l}\text { V418 definition higher reality } \\
\qquad \%\end{array}$} \\
\hline & & & & God & $\begin{array}{l}\text { higher } \\
\text { being }\end{array}$ & $\begin{array}{l}\text { don't } \\
\text { know }\end{array}$ & $\begin{array}{l}\text { doesn't } \\
\text { exist }\end{array}$ \\
\hline 1. Oxтmopox & 1.8 & 2.1 & 1.9 & 87 & 13 & 0 & 0 \\
\hline 2. Calvinist & 1.8 & 2.0 & 1.8 & 70 & 24 & 7 & 0 \\
\hline 3. REFORMED & 2.0 & 2.2 & 1.9 & 72 & 20 & 9 & 0 \\
\hline 4. CATHOLIC & 2.9 & 2.9 & 2.6 & 41 & 43 & 14 & 1 \\
\hline 5. Margenal. & 3.5 & 3.5 & 3.1 & 29 & 41 & 29 & 2 \\
\hline 6. NEW AGE & 4.2 & 4.4 & 4.1 & 5 & 47 & 42 & 6 \\
\hline 7. EX-MEMBER & 4.3 & 4.5 & 4.3 & 6 & 24 & 48 & 22 \\
\hline 8. DOURTER & 4.4 & 4.5 & 4.3 & 4 & 44 & 28 & 25 \\
\hline 9. NONBELIEVER & 4.8 & 4.9 & 4.7 & 1 & 10 & 43 & 46 \\
\hline TOTAL. & 3.7 & 3.8 & 3.6 & 16 & $3 I$ & 30 & 23 \\
\hline PEARSON $-R$ & .72 & .71 & .70 & \multirow{2}{*}{\multicolumn{4}{|c|}{$\begin{array}{l}.68 \\
.69\end{array}$}} \\
\hline ETA & .74 & .74 & .73 & & & & \\
\hline
\end{tabular}

V84 How important is it for you to: have a close relationship with God; V534 To what extent do you agree with: For me, conciliation with death is only possible by trusting God and surrender to Him; V57 How important is it for you to: be a good Christian; V418 Do you believe in a higher reality? Do you think there is a higher power or higher being, something divine or a God? Range V84 and V57: 1 = very important, 5 = very unimportant; V534: $1=$ agree totally, $5=$ do not agree at all.

15 At this point rank order is evident, but there are three clear breaking points. Between active Church members (group 1-4) and non-Church members (group 6-9) there is a substantial gap which is filled by those who do consider themselves members but do not attend Church: the marginals (group 5). Their position is as predicted and, compared to the non-Church members, they place relatively great weight on being a good Christian 
and faith in God when faced with death, but they deviate from Church members in that they place less importance on being close to God in daily life. The latter aspect is also reflected in their definition of a higher reality: marginals shift away from an image of God to a more abstract higher being, and $29 \%$ of them are in doubt.

A second breaking point occurs in the bottom half of the scale. In the non-membership groups (6-9) the figures are as predicted, but there is quite a leap between marginals (group 5) and non-members (group 6-9). The non-members (and especially the nonbelievers) are more opposed to religious interpretations and place little importance on Christian values. The word "god" is almost completely rejected. Differences between New-Age, ex-members, doubters and non-believers are small, but clearly linear.

Within the groups of active Church members (1-4), a third breaking point is visible between the Protestant groups (1-3) and the Catholics (4). For Protestants it is very important to be close to God and to be a good Christian (mean score about 2), whereas Catholics take a somewhat ambiguous position (mean score about 3). Catholics clearly less often define the higher reality they believe in as "God". A lot of them prefer words like "higher being" or "higher power". This indicates the rather precarious situation of Catholicism, in particular in Dutch society. We will see this again when we look at other variables. Catholics seem to be less religiously involved than Protestants.

But we have to be cautious. Catholics and Protestants not only differ in a quantitative but also in a qualitative sense. Protestant religion places emphasis on God as an exterior force and prefers a dialectical image of God, one in which God is "radically other than" the world (Greeley, 1990). Catholics, on the other hand, predominantly have an analogical or sacramental image of God, in which God is made present in and through the world and interpersonal relationships. Therefore Catholics are more inclined to see God as a symbol, more often doubt the existence of an actual higher being or of God, and more strongly endorse an autonomous, innerworldly meaning to human life (Greeley, 1990; Felling et al., 1991; Peters et al., 1996). So when we measure orthodoxy by asking about the importance of being close to God, faith in God and the importance of being a good Christian (as we do in Table 2), Protestants are bound to score higher than Catholics.

19 The difference between the Catholic and the Protestant way of believing was nicely described by Umberto Eco, using a computer analogy. In this view Macintosh computers are Catholic and DOS computers are Protestant: "the Macintosh is cheerful, friendly, conciliatory, it tells the faithful how they must proceed step by step to reach - if not the Kingdom of Heaven - the moment in which their document is printed. It is catechistic: the essence of revelation is dealt with via simple formulae and sumptuous icons. Everyone has a right to salvation", whereas "DOS is Protestant, or even Calvinistic. It allows free interpretation of scripture, demands difficult personal decisions, imposes a subtle hermeneutics upon the user, and takes for granted the idea that not all can reach salvation. To make the system work you need to interpret the program yourself: a long way from the baroque community of revelers, the user is closed within the loneliness of his own inner torment" (Eco, 1994). So Catholics arenot necessarily less religious than Protestants - just as a Macintosh PC is no less a computer than a DOS PC - but they are religious in a different way.

20 A second set of variables relating to religious behaviour contains weaker correlations (.31 to.71), but still linear ones (the eta does not differ substantially). They are about the meaning of life, dying and death, and about the interest in religious matters. The stronger the religious involvement, the more youngsters disagree with the proposition that people 
themselves must give meaning to life (V528). The highly religiously involved youngsters disagree that in the moment of dying, they have to face death on their own strength (V526) and as we have seen in table 2, seek conciliation with death in having faith in God and surrendering to Him. Stronger religious involvement also means believing that death is not the end (V520), but that there is a heaven or paradise (V536). And finally, stronger religious involvement means a greater interest in religious information via television, radio, articles and talking about religious matters (V405, V407, V408). (Table 3)

Table 3 - Scores of the nine religious groups on variables related to religious attitudes and activities.

\begin{tabular}{|c|c|c|c|c|c|c|c|c|c|c|}
\hline $\begin{array}{l}\text { RELIGHOUS } \\
\text { INVOt.VEMENT }\end{array}$ & $\begin{array}{c}\text { V } 528 \\
\text { self } \\
\text { meaning } \\
\text { life }\end{array}$ & $\begin{array}{l}\text { V526 } \\
\text { own } \\
\text { power } \\
\text { dying }\end{array}$ & $\begin{array}{c}\text { V520\% } \\
\text { life } \\
\text { after } \\
\text { death }\end{array}$ & $\begin{array}{l}\text { V536 } \\
\text { heaven } \\
\text { paradise }\end{array}$ & \multicolumn{2}{|c|}{$\begin{array}{c}\mathrm{V} 405 \% \text { read } \\
\text { article religion }\end{array}$} & \multicolumn{2}{|c|}{$\begin{array}{l}\text { V407\% radio } \\
\text { TV religion }\end{array}$} & \multicolumn{2}{|c|}{$\begin{array}{l}\mathrm{V} 408 \% \text { talk } \\
\text { religion }\end{array}$} \\
\hline 1. Ожтнорох & 3.5 & 4.4 & 84 & 2.0 & 62 & 4 & 27 & 39 & 54 & 0 \\
\hline 2. Calvinist & 3.6 & 4.3 & 88 & 1.9 & 41 & 14 & 14 & 16 & 47 & 4 \\
\hline 3. REFORMED & 3.1 & 4.2 & 88 & 2.0 & 27 & 15 & 23 & 17 & 40 & 6 \\
\hline 4. Слтноце & 2.4 & 3.6 & 79 & 2.3 & 17 & 29 & 3 & 45 & 21 & 7 \\
\hline 5. MARGINAL. & 2.0 & 3,3 & 60 & 2.8 & 7 & 48 & 3 & 53 & 10 & 27 \\
\hline 6. NEW AGE. & 2.0 & 2.8 & 62 & 3.7 & 7 & 33 & 4 & 43 & 19 & 14 \\
\hline 7. EX-MEMaER & 1.9 & 2.7 & 33 & 4.1 & 5 & 47 & 3 & 50 & 13 & 18 \\
\hline 8. DOUBTER & 1.8 & 2.6 & 37 & 4.1 & 3 & 54 & 2 & 58 & 9 & 20 \\
\hline 9. NONBEI IEVER & 1.6 & 2.1 & 24 & 4.6 & 2 & 61 & 0 & 66 & 5 & 31 \\
\hline Total. & 2.2 & 3.1 & 54 & 3.4 & 13 & 16 & 6 & 39 & 19 & 47 \\
\hline $\begin{array}{l}\text { PEARSON }-k \\
\text { ETA }\end{array}$ & $\begin{array}{r}-.49 \\
53\end{array}$ & $\begin{array}{r}-.55 \\
.56 \\
\end{array}$ & $\begin{array}{l}-50 \\
.53\end{array}$ & $\begin{array}{l}.65 \\
.67 \\
\end{array}$ & $\begin{array}{l}.43 \\
.46 \\
\end{array}$ & & $\begin{array}{l}.31 \\
.36 \\
\end{array}$ & & $\begin{array}{r}35 \\
38 \\
\end{array}$ & \\
\hline
\end{tabular}

21 V528 To what extent do you agree with: It's people themselves who give meaning to life; V526 To what extent do you agree with: In the moment of dying, we have to face death on our own strength and not trust any religion; V520 Is death the final end or is there life after death?; V536 To what extent do you agree with: I believe in a heaven or paradise after life; V405 Do you ever read articles on religious topics?; V407 Do you ever listen to religious radio programmes or watch religious television programmes?; V408 Do you ever have conversations about religious topics? Range V528, V526, and V536: 1 = agree totally, $5=$ do not agree at all.

22 Differences within the Protestant groups are small, but linear as expected. The only apparent exception lies in the strikingly low percentage of orthodox and especially Calvinist youngsters who watch religious television programmes, but this exception proves the rule since some of them are not allowed to watch television at all, according to the precepts of their religious creed.

Again we find a rather sharp contrast between the Protestant groups (1-3) and the Catholics (4). Catholic youngsters are more similar to the non-Church members: they agree that people themselves have to give meaning to life, and that in the moment of dying people have to face death on their own strength, whereas the Protestant groups place emphasis on trusting in God, especially in the moment of dying but, as we haveseen in table 2, also in daily life. We also see that Catholics are much less interested in information regarding religious matters.

The possibility of life after death is considered plausible by all active Church members (group 1-4, about $80 \%$ ) and the marginals (60\%), but also by New Age youngsters (62\%). However, only the Church members believe in a heaven or a paradise while for the New 
Age group life after death takes the form of reincarnation, as we will see further on in table 4.

Overall, our predictions are corroborated. The scale we devised for measuring religious involvement reflects a clear rank order. The strongest items focus on being close to God, being a good Christian and trusting God in the face of death. Differences within the Protestant groups are small, but in line with our predictions. For Protestants it is very important to be close to God and to be a good Christian. They label a higher reality almost always as "God" and they often talk about religious matters. Catholics differ remarkably from the Protestant groups, they less often define the higher reality they believe in as "God" and agree less that being a good Christian or being close to God is important. They are less interested in religion: they much less often read articles, listen to the radio or watch television.

The New Age group shows a higher interest in religion than the marginals, but looks more like the non-members on the other variables. The group of non-believers, a significant group of young people (about $17 \%$ of the population), rejects any reference to god and Christianity and is not interested in religious matters.

The group of youngsters that are engaged in New Age related activities deserves some closer attention. On several items we found curvilinear correlations (indicated by the fact that Pearson's $r$ is substantially smaller than the eta), which indicates that New Age youngsters differ significantly from other youngsters.

Table 4 - Some special characteristics of the New Age group.

\begin{tabular}{|c|c|c|c|c|c|c|c|c|}
\hline $\begin{array}{l}\text { RELKGNOUS } \\
\text { INVOLVEMENT }\end{array}$ & $\begin{array}{l}\mathrm{V} 112 \text { art } \\
\text { and } \\
\text { literature }\end{array}$ & $\begin{array}{l}\text { V113 } \\
\text { beauty }\end{array}$ & $\begin{array}{c}\text { V80 } \\
\text { personal } \\
\text { developucht }\end{array}$ & $\begin{array}{l}\text { V489 } \\
\text { castem } \\
\text { wisdom }\end{array}$ & \begin{tabular}{c|c|} 
VS38 \\
reincarnation
\end{tabular} & $\begin{array}{l}\text { v280\% } \\
\text { political } \\
\text { party green } \\
\text { left }\end{array}$ & $\begin{array}{c}\text { V299\% } \\
\text { participation in } \\
\text { demonstrations }\end{array}$ & $\begin{array}{c}\text { V512. } \\
\text { psychological } \\
\text { problems }\end{array}$ \\
\hline 1. ORTHODOX & 3.2 & 2.6 & 1.6 & 3.5 & 4.4 & 19 & 32 & 3.0 \\
\hline 2. Calvinist & 3.2 & 2.6 & 1.7 & 3,8 & 4.3 & 16 & 24 & 3.1 \\
\hline 3. REFOKMED & 3.3 & 2.8 & 1.7 & 3.9 & 4.4 & 9 & 25 & 3.4 \\
\hline 4. Catholic & 3.2 & 2.6 & 1.6 & 3.4 & 3.5 & 4 & 22 & 3.3 \\
\hline 5. Marginal. & 3.5 & 2.6 & 1.7 & 3.8 & 3.6 & 13 & 22 & 3.1 \\
\hline 6. NEW AGE & 2.6 & 2.0 & 1.3 & 2.8 & 3.0 & 28 & 52 & 2.4 \\
\hline 7. EX-MEMBER & 3.0 & 2.4 & 1.6 & 3.5 & 4.3 & 24 & 46 & 2,9 \\
\hline 8. Dotatex & 3.0 & 2.6 & 1.5 & 3.6 & 3.8 & 19 & 32 & 3.0 \\
\hline 9. NONBHLJEVER & 3.0 & 2.4 & 1.5 & 3.6 & 4.1 & 24 & 43 & 3,3 \\
\hline TOTAL. & 3.0 & 2.5 & 1.6 & 3,5 & 3.9 & 19 & 36 & 3.0 \\
\hline PeARSON $-\mathrm{r}$ & -12 & -.08 & -.07 & -.04 & -.01 & & -14 & -01 \\
\hline ETA & 23 & .21 & .19 & 28 & 39 & & .24 & 22 \\
\hline
\end{tabular}

VI12 How important is it for you to: Spending a lot of time on art and literature; VI13 How important is it for you to: Experience beauty; V80 How important is it for you to: Develop one-self; V489 How important has the following event or experience been in the way you see the meaning of life: Getting acquainted with Eastern sources of wisdom; V538 To what extent do you agree with: I am convinced reincarnation exists; V280 What political party do you prefer. Percentage that preferred the green left political party; V299 Have you ever participated in a political demonstration; V512 How important has the following event or experience been in the way you see the meaning of life: Psychological problems of oneself. Scales V112, V113, V80, V489, V538, V512 range from 1 (strongly agree) to 5 (strongly disagree).

On the items in table 4, the New Age youngsters score higher than both the orthodox and the nonbelievers. New Age youngsters are more interested in art and literature (V112), in 
experiencing beauty (V113), and they place greater weight on personal development (V80). They are more interested in Oriental wisdom (V489) and believe more strongly in reincarnation (V538). Politically they are left-wing oriented (V280), and they are more revolutionary in their political opinions and actions (V299). Furthermore, they report that personal psychological problems have been important in relation to the meaning of life (V512). These results correspond with research by Baerveldt (1996), who found that people for whom New Age constitutes a philosophy of life have a drive to personal development and personal growth, are engaged in social affairs and are politically (moderately left-wing) active. Baerveldt also found a second group of people who participate in New Age activities to solve psychological problems. This group lacks the social and political involvement of the first group and for them New Age functions rather as an individual therapy and not as a form of religiosity (Baerveldt, 1996).

It can be summarised, on the basis of the linear and curvilinear correlations found in Tables 2, 3 and 4, that our index of religious involvement, which is based on historical and individualised variables, is highly precise and valid. It takes account of historical and recent developments, social structure and individual behaviour. But given the validity of our scale, it is all the more striking that it does not correlate in the least with all kinds of opinions, ideals and behaviour that matter in the daily life of the young. When asked about the role that partners, parents, the environment, injustice, sex, health, work, education, love, music and politics play to give life meaning, we found not one substantial correlation with religious involvement.

The differences are small and it is unclear how to interpret them. In variables concerning daily life, we do not find a link with religious involvement as we found earlier: there is no linear nor any curvilinear correlation or coherence.

The only (weak) correlations between religious involvement and behaviour in daily life lie in the realm of "rites de passage". The degree of religious involvement turns out to be a weak structuring force in the passage from adolescence to adulthood in some cases. We looked for a relation between the categories of religious involvement and the age people are allowed to do things or are expected to think about things and be responsible. It turns out that such a relation exists only in the case of marriage, dancing courses and the first time to have sex.

The greater the religious involvement, the later in their lives do youngsters participate in a dancing course (especially the Orthodox Protestants and the Calvinists), go on a holiday by themselves and have sex for the first time (and it is the Orthodox in particular who postpone this moment). Conversely, the greater the religious involvement, the sooner the youngsters expect to get married. There are hardly any differences between the moments that our respondents realise the limits of what men can achieve, contemplate the meaning of death, worry about their future, are seen as adults or drive their own car.

Religious involvement thus has a rather small effect on daily life. Other studies obtained the same results (Voyé, 1988; Van der Linden, 1989; Alma \& Heitink, 1994; Dekker et al., 1997). As Fuchs (1985) concluded for the German youth, we can conclude for the Dutch: religion seems to have no structuring value for everyday life. But again we have to be careful. The mean scores in table 5 are rather high. So whilethere is no difference between the religious groups, overall young people think that daily life is important for giving meaning. As Van der Linden (1989: 120) concluded from a national survey among the Dutch youth: "The terminology of the young without belief strongly corresponds with what believers say about giving meaning to life". To understand this we have to study 
more deeply the religion of the youth, not just as a sociological variable but as a daily practice.

\section{What young people do and think: prayer and the image of God}

In Europe, Church membership varies substantially from country to country and the Dutch youth have a prominent place, but there are striking similarities between the opinions of all the young, including the Dutch. In countries like England (Furnham \& Gunter, 1989), Germany (Barz, 1992), France (Cousin et al., 1985; Lambert \& Michelat, 1992) and Belgium (Hutsebaut \& Verhoeven, 1991) social researchers conclude that the young share a lack of interest in official, institutional religion but at the same time they find that only a small minority prefer atheism (Campiche, 1997). Youngsters have a primarily experiential and experimental outlook on religion. Religion is home-made on the basis of personal experiences concerning important life events. Prayer in particular is a widespread and important individualised ritual for the young: while only $39 \%$ of the Dutch youth say to be members of Churches, $82 \%$ say they pray, at least sometimes. In the European studies (Campiche, 1997: 52) the Dutch youth are in third place after Ireland and Italy (among 16 countries) on prayer. And this time, and that is exceptional, there is hardly any difference with the elder generation (18-29 years: 61\%; 60 years and older: $68 \%$ ).

To understand the religiosity of today's youth, it seems central to understand what their prayer is about. We asked them to tell us in their own words what prayer is, why they pray, when they pray and how they pray. At the basis of the prayer of the young, as our analysis shows, is the well-known tripartite structure of the ritual: when in trouble (mostly concerning other people) people start an activity (mostly asking or hoping) to cope with the trouble (mostly on an emotional level): so we have a need, an action and an effect (see Table 5).

Table 5 - Frequencies within a model for praying practices of modern young people. $\mathrm{N}=687$

\begin{tabular}{|c|c|c|}
\hline \multirow[t]{3}{*}{$\begin{array}{l}\text { 1. Need }(408) \quad \overrightarrow{ } \\
\text { (negative }(346) \text {, others }(207) \text { ) }\end{array}$} & $\begin{array}{l}\text { 2. Action }(561) \\
\text { (ask/hope }(201) \text {, meditate }(197) \text { ) }\end{array}$ & $\begin{array}{l}\text { 4. Effect (398) } \\
\text { (emotional }(286) \text { ) }\end{array}$ \\
\hline & 3. Direction (330) (God (207)) & \\
\hline & $\begin{array}{l}\text { 5. Time (385) (at night }(223)) \\
\text { 6. Place }(403) \text { (in bed }(215)) \\
\text { 7. Method (394) (eyes closed (1) }\end{array}$ & hands joined (104) \\
\hline
\end{tabular}

Furthermore, although we did not ask the young about the direction of their prayer, most of them spontaneously mentioned a direction, an addressee, mostly called God. What God looks like for these youngsters, we will discuss later. For now, we will focus on the need, action, direction and effect, in an attempt to distinguish between differenttypes of prayer (Janssen et al. under review). Depending on the centrality of one of these four elements, we predicted four kinds of prayer. If the emphasis is on the effect (wanting to be cured), we have a "primitive" prayer; if the emphasis is on the direction (God) we are dealing with a "religious" prayer; if the action of praying as such is central, the prayer is called "meditational"and if the need, the coping element is paramount, we speak of a "psychological" prayer. However, factor analysis showed that in our sample of Dutch 
youths primitive and religious prayer are empirically the same, so we summarised the two as religious. It also turned out that each prayer is a combination of these three types of prayer. So it is more appropriate to speak of three aspects of prayer: successively religious, meditational and psychological.

An unexpected finding is the importance of method, time and place. Every type of prayer has its own set of adjuncts. Young people who pray anytime and anywhere, say a meditational prayer. Religious prayer is said quietly, at fixed moments in church and often uses formulas. Psychological prayer is done at night, lying in bed with hands joined and eyes closed. So place, time and method are much more important than was foreseen and are not just (adverbial) adjuncts loosely connected to a sentence of more central importance. Durkheim (1912) already emphasised passim the importance of religion as structuring time and place. In the middle ages, time was named after the prayer that was said (for instance compline and vespers), but in our times, too, times and places are structured by religion.

Religious involvement determines the way youngsters pray. First of all we find that the more religiously involved youngsters pray more often and give more complex and richer definitions of prayer. Protestants show more expertise than Catholics and the latter more than non-believers. There is a major correlation between the nine categories and the prevalence of religious praying elements: Pearson r.40 (Janssen et al. under review), and also between praying frequency and the number of structural elements mentioned: Pearson r.45 (Janssen et al., 1990). Competence and experience leads to a more complete and more extensive prayer. The Protestant and the Catholic prayers are also different with respect to the content and the style of the prayer. Catholics use more formulas and Protestants more often pray with eyes closed and hands joined (Janssen et al., 1990). The characterisation which psychologist James Bisset Pratt once gave of the Catholic and the Protestant prayer still holds: a Catholic priest, he said, prays in silence, alone, mumbling and repeating formulas. A Protestant minister prays openly, loud and clear, in front of an audience, hands joined and eyes closed. He tries to formulate "the most eloquent prayer ever addressed a Boston audience" (Pratt, 1920: 297-298).

These differences notwithstanding, there is great similarity between the prayer of the young especially on the meditational and the psychological aspects. Neither of them are correlated with religious involvement. On the whole we can characterise the prayer of the young as psychological by nature: when confronted with specific and negative events, in particular the death of relatives, youngsters pray in order to find the strength to go on. The problem is concrete, but cannot be solved, so the desired effect is a psychological change within the praying person. The action is meditational in that youngsters do not communicate or talk, but ponder and think. Only a small segment of the youth add religious elements to this structure of prayer: they thank God or ask for real effects. Even when youngsters ask for real effects, they use their prayer as a concentrated motivation (Janssen et al., 1990). Youngsters typically pray when examinations are upcoming, but they do not ask for good results, instead they ask forconcentration and being able to study well. However, for most young people praying is a coping mechanism, a kind of non-directional therapy that they apply to keep their life in balance (Janssen et al., 1990; Janssen et al., under review).

41 It is when they have to face important problems that people turn to religion. Young people, for the first time in their lives, get confronted with problems that are by their very nature insoluble, like the death of loved-ones. Several studies have shown that 
experiences with death, and in particular the death of personal acquaintances, are the major causes for youngsters to reflect upon the meaning of life or for the rise of religious experiences (De Hart, 1994). However, youngsters nowadays do not turn to institutionalised religion, they prefer a privatised religious practice: they pray - as we have seen - when they are alone, in bed, at night, with their eyes closed (see Table 5). Both time and place are significant. In today's hectic and busy life, no time is left for silence and meditation. In bed people are finally on their own and find an opportunity to contemplate the day in silence and solitude. The paramount reality of everyday life is interrupted and, between active thought and deep sleep, the brain activity is reduced to a mode of passive receptivity that prepares one to "turn inwards" and meditate the contradictions of daily life (Spilkaetal., 1985; Janssen et al., 1990).

Interpreting these findings Liliane Voyé (in Campiche, 1997: 141) characterised the prayer of the young as an individualised, do-it-yourself confession. We think this an interesting and suitable interpretation. In prayer feelings of guilt, disappointment and deficiency are coped with. New intentions and plans can be made. So prayer has important psychological functions in the construction of identity. It is not meant, as St. Augustine already said, to instruct God but to construct oneself: "ut ipsa (mens) construatur, not ut Deus instruatur" (Epistola CXL, caput XXIX, 69). Prayer is a mechanism to make an inventory of daily events and to learn to accept the inevitable.

Although the young pray privately, in darkness and in bed, they are not alone. They spontaneously mention a direction in their prayer, mostly called God. But who is God for people who largely say not to belong to any Church? To answer this question we did a separate study (Janssen et al., 1994). Again we used open ended questions and analysed the texts of the young. When we compare our results with some findings in the European Values Studies, it becomes clear how important it is to let the young themselves talk about religion, answering minimal questions. When the young Dutch were asked whether they pray, many gave a positive answer and there was hardly any difference between them and the older people (61\% versus $68 \%$ ). But when they are asked whether they pray to God the number decreases considerably and a sizeable difference with their elders appears (Campiche, 1997: 11\% versus 42\%). At the same time when talking about their own religious practices the young spontaneously use the word "God", and rather often (Table 7; Janssen et al., 1994; Janssen et al. under review). So we have to conclude that the meaning of the word is different in different contexts. In questionnaires the word "God" is related to institutional religion, in their own language the young reinvent the word to label a central element that they cannot define in another way. The young have their own "native religious grammar"(Lind-beck, in: Van der Ven, 1992).

When we ask the young who this God is they talk about, they use all kinds of words and metaphors. It seems as if they construct their own definition on the spot. Hutsebaut and Verhoeven (1989) found in a Belgian panel study that there is no correlation between the definitions of God that young people gave at the age of 12 andthe age of 15. It seems that, like our respondents, they lack a common stock of words and metaphors. In a Dutch study, youngsters reported that they were unable to give answers to the well-known Vergote/Tamayo questionnaire on the image of God because, in their view, the items were not suitable (anymore) to describe God (Mischke \& Wittenberg, 1990). Traditional images of God have lost credibility. Young people prefer a vague and abstract representation of God. They devoutly practice the mission from Jim Morrison's An American prayer: "Let's reinvent the Gods". 
As the traditional concepts and representations of God seem to be out of use, and new ones yet in construction, we have to ask youngsters to tell us about their God in their own words. Therefore we used open ended questions. When we look for common concepts that the young use to describe God, we first find that God is more often described as an activity than as a being. In $32 \%$ of the definitions they say "God is", in $75 \%$ of their texts they say "God does". The most mentioned activities of God are wielding power and supporting people. We further found that the images of God can hardly be specified in parental terms or gender. Although God is generally referred to as "he" ( $82 \%$ of the texts), God is called a man in only $6 \%$ of the texts, and father or mother figures are rarely used as images of God. When forced to choose, God is mostly called a man (52\%) and a father (28\% ), but in the further commentaries our respondents gave they explicitly refer to traditional pictures and stories: God is a man, so says the Bible and he is generally depicted as such in paintings and drawings (Janssen et al., 1994). As the European studies show, the majority of the Dutch youth define God as a spirit or force, not as a person (Campiche, 1997: 108; see also Van der Ven, 1992).

We conclude that to describe God Dutch young people primarily use indefinite, impersonal and abstract terms: God is someone or something exercising some kind of power on people. We do not know him but see his acts (Janssen et al., 1994). The idea of God, as Pratt (1920: 207) put it, "has a large pragmatic element". Or, in the words of Leuba (1901: 571): "God is not known, he is not understood, he is used". God is reinvented on the basis of daily practice.

\section{Conclusion and discussion}

"Our time is a time of religious decline. The once enduring vitality of the religious is in decay. (...) Youth is in open conflict with the established society and with the authority of the past. They experiment with eastern religions and techniques of meditation. The greater part of mankind is affected by the decay of the times" (in Borchert, 1994). There is no doubt that the religious landscape of Europe is in turmoil and will change dramatically in the next decades. The differences between the young and the older people are great and point especially to a decreasing saliency of traditional, institutional religion. Today even the core believers among the young have ideas and practices that deviate fundamentally from official prescriptions and they differ substantially from the elder generation. However, the above-mentioned gloomy picture of culture and the state of religion was written in the late first century $\mathrm{AD}$ by Tacitus and refers to the state of the old Hellenistic world. In all ages younger generations deviate from the footsteps of their predecessors who regret and criticisethis deviation. "Rade volte risurge per li rami L'umana probitate" ("Rarely does human worth rise through the branches") Dante sighed in Purgatory (VII,121-122); and in Paradise (VIII, 93) he desperately wonders: "Come uscir puo di dolce seme amaro" ("how from sweet seed may come forth bitter"). Social scientists can share Tacitus' and Dante's concern without borrowing their moralistic overtone. As a matter of fact Dante also accepted that the young have to go their own way (Paradise VIII, 127-135). We do not know why, they do not know how. For the time being they are groping in the dark, let us say wandering in a dark wood. They doubt, they hesitate, they advance by trial and error (Campiche, 1997: 144).

In our society the problems Tacitus and Dante described coincide: culture is changing rapidly and can hardly be transferred from one generation to another as a complete 
package of beliefs, values and guidelines for behaviour. Achieving culture has become more and more a process of construction, of actively acquiring a personalised set of beliefs, values and guidelines for behaviour. This pragmatic, trial and error way of thinking and constructing meaning is shared by young people participating in today's youth culture. They have to construct their culture and thus their religion over and over again. Modern youth culture has been characterised as a do-it-yourself-culture (Janssen, 1994: 37). Youngsters are really "bricoleurs" according to "Lévi-Strauss"famous dictum (Lévi-Strauss, 1962). They are no "ingenieurs"who draw up plans and sketches and share a history as professionals. The "bricoleurs" are amateurs who act from the concrete, inventing by recombining what is present in their daily life situation. They have no history: life starts afresh every day. They cannot be pinned down on their plans and intentions. They have none. The drawing of their buildings can only be made when the building is finished. Moreover, they do not want to be members of fixed groups. They try to escape common formulas and do not want to be labelled. The concept of social groups is elusive because youngsters themselves hardly ever use conceptions of social groups or categories (Widdicombe \& Wooffitt, 1995). Even a clear-cut punk, who knows perfectly well that others have no choice than to see him as a punk, has a tendency - as research shows (Janssen \& Prins, 1991) - to say he is not a punk. He is primarily himself, unique and undefinable.

Like their culture, the religion of the young is in flux, unstable, changing, reinvented every day. Beliefs and practices are afloat in a process of eclecticism and bricolage (Schlegel, 1997: 29). Only a minority see the bright light of atheism, another minority carry the blinding torch of fundamentalism. Youngsters more often construct a personal framework of meanings by choosing from religious and ideological ideas that are available on the "spiritual marketplace" at the present time (Felling et al., 1991). In this eclectic process, religious institutions have lost their monopoly, and although youngsters still draw on religious traditions, they use them more as "a toolbox of symbols than a sense of community or belonging" (Fulton on Hervieu-Leger, 1997). As Van Baal (1979) pointed out: "new symbols are not found, they are created and creating is exceedingly rare. (...) Modern man is not even able to create a single new word. Whenever we need a new term or expression, we borrow words from a foreign language, reshape them a bit and thus we make a new term. We make it, but do not create". In this way, young people nowadays borrow symbols and create their own religion. The religion of the majority of the youth is an open ended question par excellence. Many say they do not believe but do have an idea of God, many others say they believe but have no idea of God. The prayer of one of our respondents may be exemplary for the religion of the young. He said: "I pray to God in whom I don'tbelieve, that He will help my friend who does believe in Him, if he exists" (Janssen et al., 1994). How can one be more honest to God?

The rise of the New Age movement ties in with this modern attitude towards religion. New Age can be seen as a prototypical form of a "do-it-yourself" religion (Baerveldt, 1996). Where the traditional Churches are characterised by membership and a clear structure and organisation, New Age does not have such a clear structure. New Age does not organise people in groups, but in networks. Not membership, but consumption is central. More and more young people reject religious doctrines and instead adopt a seeking and experimenting attitude regarding the philosophy of life. Although for a portion of the New Age interested people, motivation lies in the realm of individual therapy, for another group New Age activities do provide a way of giving meaning to 
their lives (Baerveldt, 1996). New Age is not a ready-made belief system that replaces traditional religion, it is vague, undefined and continuously changing. This indicates that there is a shift, not from belief to disbelief, but from belief to seekership, as Campbell put it (in Barker, 1982). This seekership can be placed in the context of advanced industrial society, as Inglehart does, where he sees a postmaterialist world-view emerging among the younger generation, with a relatively great concern for the meaning of life, and a renewed emphasis on the sacred, albeit "sacred in nature rather than in Churches" (Inglehart, 1990: 433).

51 The religion of the youth is not just their affair. It is embedded in our culture, perhaps it is the herald of the future, perhaps it tells us something about the essence of religion. In last June the international journal Esprit characterised our times as "les temps des religions sans Dieu" ("the times of the religions without God"). There is a general tendency to define God in an unspecific, abstract and impersonal fashion. If this is a variation on atheism, it can be a wholesome one. In a book on Christian mysticism, Bruno Borchert stresses the religious dimension of today's atheism: “it does not arise out of scepticism and indifference but out of a loss of faith in old images and an inability to find new ones. This lack of contact with God can prove to be a good breeding ground for a fresh form of mysticism" (Borchert, 1994: 165). We share the optimistic expectations of Roland Campiche (Campiche et al., 1992) and Ronald Inglehart (1990), that the individualised religion of the young is not just a sign of dechristianisation but can be the basis of a recomposition of religion.

\section{BIBLIOGRAPHY}

ALMA Hans, Geloven in de leefwereld van jongeren, Kampen, Uitgeverij Kok, 1993.

ALMA Hans, HEITINK Gerben, "Having faith in young people's worldview and their lifepattern", in Journal of Empirical Theology, 7 (2), 1994, 52-74.

BAAL Jan van, “Changing religious systems", in Pieter Hendrik VRIJHOF \& Jacques WAARDENBURG, eds, Official and Popular Religion. Analysis of a theme for religious studies. The Hague, Mouton Publishers, 1979.

BAERVELDT Cor, "New Age-religiositeit als individueel constructieproces", in Miranda MOERLAND, ed, De kool en de geit in de Nieuwe Tijd: wetenschappelijke reflecties op New Age, Utrecht, Van Arkel, 1996.

BARKER Eileen, ed, New religious movements: a perspective for understanding society, New York, Edwin Mellen Press, 1982.

BARZ Heiner, Religion ohne Institution? Jugend und Religion, Opladen, Leske + Budrich, 1992.

BECKER Johan \& VINK René, Secularisatie in Nederland 1966-1991, Rijswijk, Sociaal en Cultureel

Planbureau, 1994.

BECKER Johan, DE HART Joep \& MENS Jann, Secularisatie en alternatieve zingeving in Nederland, Rijswijk,Sociaal en Cultureel Planbureau, 1997. 
BERNTS Ton, Meer stem voor jongeren: een onderzoek naar jongerenkoren, religiositeit en kerk, Nijmegen, ITS, 1995.

BORCHERT Bruno, Mystiek. Het verschijnsel, de geschiedenis, de nieuwe uitdaging, second, revised print, Haarlem, Gottmer, 1994.

CAMPICHE Roland J., DUBACH Alfred, BOVAY Claude, KRUGGelER M. \& voll P., Croire en Suisse(s), Lausanne, Édition L'Âge d'homme, 1992.

CAMPICHE Roland J., ed., Cultures des jeunes et religions en Europe, Paris, Cerf, 1997.

COUSIN Pierre, BOUTINET Jean-Pierre \& MORFIN Michel, Aspirations religieuses des jeunes lycéens, Paris, L'Harmattan, 1985.

DE HART Joep, Levensbeschouwelijke en politieke praktijken van Nederlandse middelbare scholieren, Kampen, Kok, 1990.

DE HART Joep \& JANSSEN Jacques, “New Age als paracultuur”, in Voorwerk, 1, 1992, 14-24.

DE HART Joep \& JANSSEN Jacques, “Jongeren en politiek", in Arjan DIELEMAN, Frans VAN DER LINDEN \& Sandra PERREIJN, Jeugd in meervoud, Utrecht, Uitgeverij De Tijdstroom bv, 1993.

DE HART Joep, Jongeren na de middelbare school. Levensbeschouwelijke opvattingen, waardeoriëntaties en sekseverschillen, Kampen, Uitgeverij Kok, 1994.

DEKKER Gerard, DE HART Joep \& PETERS Jan, God in Nederland. 1966-1996, Amsterdam, Anthos, 1997. DURKHEIM Émile, Les formes élémentaires de la vie religieuse. Le système totémique en Australie, Paris, Alcan, [1912] (1960).

Eco Umberto, “La bustina di Minerva”, Umberto Eco's back-page column in the Italian news weekly Espresso, 30 September 1994.

FELLING Albert, PETERS Jan \& SCHREUDER Osmund, Dutch religion. The religious consciousness of the Netherlands after the cultural revolution, Nijmegen, ITS, 1991.

FUCHs Werner, "Konfessionelle Milieus und Religiösität”, in Jugendliche + Erwachsene ‘85, Band 1, 265-304,Leverkusen, Leske \& Budrich, 1985.

FULTON John, "Modernity and religious change in western Roman Catholicism: two contrasting paradigms", in Social Compass, 44 (1), 1997, 115-129.

FURNHAM Adrian \& GUNTER Berrie, The anatomy of adolescence. Young people's social attitudes in Britain, London, Routledge, 1989.

GREELEY Andrew M., The Catholic Myth: the behavior and beliefs of American Catholics, New York,Scribner's, 1990.

HANEGRAAFF Wouter J., New Age religion and western culture: esotericism in the mirror of secular thought, Leiden, Brill, 1996.

HUTSEBAUt Dirk \& VERHOEVEn Dominic, “The adolescents' representation of God from age 12 until age 15",in Proceedings of the fourth symposium on the psychology of religion in Europe, Nijmegen, Universityof Nijmegen, 1989, 147-156.

HUTSEBAUT Dirk \& VERHOEVEN Dominic, “The adolescents' representation of God from age 12 until age 18: Changes or evolution?", in Journal of Empirical Theology, 4, 1991, 59-73.

INGLEHART Ronald, Culture shift in advanced industrial society, Princeton, New Yersey, Princeton UniversityPress, 1990. 
JANSSEN Jacques, Tekst-tabel, Nijmegen, University of Nijmegen: Department of psychology, 1990. JANSSEN Jacques, DE HART Joep \& DEN DRAAK Christine, “A content analysis of the praying practices of Dutch youth”, in Journal for the Scientific Study of Religion, 29, 1990, 99-107.

JANSSEN Jacques \& PRINS Maerten, “Jeugdsubculturen binnenstebuiten: een onderzoek naar de homologie van jeugdsubculturen", in Jeugd \& Samenleving, 2/3, 1991, 194-212.

JANSSEN Jacques, DE HART Joep \& GERARDTS Marcel, “Images of God in adolescence”, in The International Journal for the Psychology of Religion, A, 1994, 105-121.

JANSSEN Jacques, Jeugdcultuur. Een actuele geschiedenis, Utrecht, De Tijdstroom, 1994.

JANSSEN Jacques, “The Netherlands as an experimental garden of religiosity. Remnants and renewals", in Social Compass, 45 (1), 1998, 101-113.

JANSSEN Jacques, PRINS Maerten, BAERVELDT Cor \& LANS Jan van der (under review), The structure and variety of prayer. An empirical study of Dutch youth.

LAMBERT Yves \& MiCHELAT Guy, eds, Crépuscule des religions chez lesjeunes? Jeunes et religions en France, Paris, L’Hartmattan, 1992.

LEUBA James H., “The contents of religious consciousness”, in The Monist, 11, 1901, 536-573.

LÉVI-STRAUSS Claude, Le totémisme aujourd'hui, Paris, Presses Universitaires de France, 1962.

LINDEN Frans J. van der, Groot worden in een klein land. Feiten en cijfers uit het onderzoek naar de leefwereld van jongeren tussen 12 en 21 jaar, Nijmegen, ITS, 1989.

MISCHKE Kersti \& WITTENBERG Maaike, Godsbeelden. Een analyse op een steekproef van Nederlandse studenten met gebruikmaking van de Semantic Differential Parental Scale (SDPS) van Tamayo \& Vergote, intern rapport, Nijmegen, Katholieke Universiteit Nijmegen, Vakgroep Cultuur- en Godsdienstpsychologie, 1990.

PETERS Jan \& SCHREUDER Osmund, Katholiek en Protestant: een historisch en contemporain onderzoek naar confessionele culturen, ITS, Nijmegen, 1987.

PETERS Jan, VAN HEMERT Murtien. BERNTS Ton \& SPRUIT Leo, Geloven in deze tijd. Onderzoek en perspectief. Den Haag, KASKI, 1996.

PRATT James Bissett, The religious consciousness. A psychological study. New York, Macmillan, 1921 [1920].

PRUYSER Paul W., Between belief and unbelief,New York, Harper \& Row, 1974.

ROES Jan, In de kerk geboren. Het Nederlands katholicisme in anderhalve eeuw van herleving naar overleving, Nijmegen, Valkhof Pers, 1994.

SCHLEGEL Jean-Louis, "Du christianisme au bouddhisme: les pratiques religieuses aujourd'hui”, in Esprit, 6, 1997, 20-30.

SPILKA Bernard, HOOD Ralph W. \& GORSUCH Jr. Richard L., The psychology of religion: an empirical approach, Englewood Cliffs, N.J., Prentice-Hall, 1985.

STENGER Horst, “Der 'okkulte’ Alltag”, in Zeitschrift fur Soziologie, 18 (2), 1989, 119-135.

VEN Johannes A. van der, "God in Nijmegen: een theologisch perspectief: over het empirisch onderzoek naar de 'sensus fidei', respectievelijk 'sensus fidelium”, in Tijdschrift voor Theologie, 32 (3), 1992, 225-249. 
VEN Johannes A. van der \& BIEMANS Berdine, Religie in fragmenten: een onderzoek onder studenten, Weinheim/Kampen, Deutscher Studien Verlag/Kok, 1994.

VEN Johannes A. van der, "Het religieus bewustzijn van jongeren en de crisis van het jongerenpastoraat", in Praktische theologie: Nederlands tijdschrift voor pastorale wetenschappen, 22 (3), 1995, 342.

VOYÉ Liliane, «Les jeunes et le corps stigmatisé », in Roberto CIPRIANI \& M. I. MACCIOTTI, eds, Omaggio a ferrarotti, Rome, Siares, Studi e Recerce, 1988, 543-556.

WIDDICOMBE Sue \& WOOFFITT Robin, "Social identities and social groups", in The language of youth subcultures. Social identity in action, Hertfordshire, Harvester Wheatsheaf, 1995.

\section{ABSTRACTS}

A process of secularisation can be observed in all European countries: church membership declines and religious institutions lose their monopoly. This is strongest among Dutch youngsters, but it does not automatically lead to a loss of religion. Instead it is a process of individualisation of religion. Youngsters nowadays construct a personal framework of meaning by choosing from available religious traditions in a process of bricolage, just as they do when they construct youth culture. Since $82 \%$ of Dutch youngsters pray at least sometimes, prayer seems to be the most persistent religious element. There is great similarity between the way the young pray: it is psychological by nature in that it gives strenght to accept the inevitable like the death of a relative, and the action of praying is meditational in that youngsters ponder and think. Prayer functions as a mechanism to make an inventory of daily life and as a therapeutic ritual to keep their life in balance. It is typically performed when they are alone, in bed, at night. Youngsters spontaneously mention God as the direction of their prayer, but they define God using impersonal and abstract terms.

Le processus de sécularisation est présent dans tous les pays d'Europe: déclin de l'appartenance à l'Église, perte de monopole des institutions religieuses. Cela est particulièrement vrai de la jeunesse néerlandaise. Cela ne signifie pas l'abandon de la religion, mais plutôt qu'on assiste à un processus d'individualisation de la religion. Les jeunes d'aujourd'hui «bricolent » leur système de sens personnel en sélectionnant parmi les traditions religieuses disponibles, en procédant de la même manière que pour la culture jeune. 82 \% des jeunes Néerlandais prient, au moins, de temps en temps, ce qui fait de la prière l'indicateur religieux le plus résistant. La façon dont ils prient est assez homogène: à caractère psychologique, la prière leur donne la force d'accepter l'inévitable, telle que la mort d'un proche; elle leur offre un espace de méditation et de réflexion; la prière les aide à faire le bilan de leur vie au quotidien, elle fonctionne comme un rituel thérapeutique qui leur assure un équilibre. Ils y recourent de préférence quand ils sont seuls, couchés, la nuit. Les jeunes désignent spontanément Dieu comme le destinataire de leur prière, mais pour définir Dieu ils usent de termes impersonnels et abstraits.

El proceso de secularizatión está presente en todos los países de Europa : declinación de la pertenencia a la Iglesia, pérdida de monopolio de las instituciones religiosas. Eso se da de manera muy visible en la juventud neerlandesa. Esto no significa que se abandona la religión sino que se produce un proceso de individualization de la religion. Los jóvenes de hoy 'hacen bricolage' de su sistema de sentido personal seleccionando entre tradiciones religiosas disponibles, tal como proceden en et campo de la cultura. El 82 \% de los jóvenes Neerlandeses rezan, por to menos de vez en cuando, siendo por eso las oraciones el indicador religioso más resistente. Entre ellos, la manera de rezar es bastante homogénea : de carácter psicológico, la oración les da fuerza para 
aceptar lo inevitable, como elfallecimiento de unfamiliar, les ofrece un espacio de meditatión y de reflexión; los ayuda a hacer el balance de su vida en lo cotidiano, y funciona como un ritual terapéutico que les asegura cierto equilibrio. Los jóvenes rezan preferentemente cuando están solos, acostados, de noche. Designan espontáneamente a Dios como el destinatario de su oración, pero cuando describen a Dios usan términos impersonates y abstractos.

\section{AUTHORS}

\section{JACQUES JANSSEN}

Catholic University of Nijmegen, The Netherlands

\section{MAERTEN PRINS}

Catholic University of Nijmegen, The Netherlands 